Gadjah Mada International Journal of Business

September 2002, Vol. 4, No. 3, pp. 327-346

\title{
REAL STOCK RETURNS, INFLATIONARY TRENDS AND REAL ACTIVITY: Evidence from Malaysia
}

\author{
M. Shabri Abdul Majid
}

This study explores the relationship between real stock returns and inflationary trends in the Malaysian economy. It attempts to test for the relationship between real stock return and inflation in light of Fisher hypothesis that asserts the independence of real stock return and inflation and Fama's (1981) proxy effect framework which states that the negative real stock returns-inflation is indirectly explained by a negative real economic activity-inflation and a positive real stock returns-real economic activity relationships. The finding shows that real stock returns are independent of inflationary trends in accordance with the Fisher hypothesis, which implies that the Malaysian stock market provides a good hedge against inflation. The Fama's proxy hypothesis is then tested to check for the consistency of the relationships. The positive relationship between inflation and real economic activity and the positive relationship between real stock returns and real economic activity that totally contradicts the Fama's proxy hypothesis however are found, to some extent, be consistent with the explanation of conventional macroeconomic theories of the Philip's curve.

Keywords: ARIMA; Fama's (1981) proxy effect; Fisher hypothesis; inflationary trends; Philips curve; real stock returns 


\section{Introduction}

The inquiry of stocks being a better hedge $^{1}$ against inflation has been widely researched and documented. The notion that stocks retain real value regardless of the inflation rate fluctuations is consistent with classical investment theories found in Day (1984) and Marshall (1992). However, progressive empirical studies in the developed countries have documented that expected inflation, unexpected inflation, and changes in expected inflation were all negatively related to stock returns which appears contrary to both economic theory and common sense. ${ }^{2}$

In the view of Fisher hypothesis, real stock returns are independent of inflationary expectations. This indicates that nominal asset returns should be positively related to both expected and unexpected inflation. The Philips curve shows that a negative relationship between unemployment rate and the rate of inflation implies a positive association between inflation and real economic activity. Therefore, stock returns that are positively correlated with real economic activity, in turn, are expected to show positive association with inflation. The positive relation between stock returns and unexpected inflation suggests that common stocks is good hedge against unexpected inflation.

There are a number of theories to explain the negative real stock returnsinflation relationship. For example, Chatrath etal. (1997) have adopted Fama's
(1981) model to explain the above relationship through a hypothesized chain of macroeconomic linkages that have their basis in the money-demand theory and the quantity theory of money. Geske and Roll (1983), Kaul (1987 and 1990), Marshall (1992), and Graham (1996) have explored the role of the monetary sector in order to explain this perplexing negative relationship between stock returns and inflation. They found the relationship to vary over time in a systematic manner depending on the influence of money demand and supply factors. Unlike Geske and Roll (1983), Kaul (1987 and 1990), Marshall (1992), and Graham (1996), Hamburger andZwick (1981) considered both monetary and fiscal policies in describing the negative real stock returns-inflation relationship.

Generally, research results have shown a negative real stock return-inflation relationship, implying that the stock market is not a good hedge against inflation. However, Ram and Spencer (1983) adopt the Mundell-Tobin hypothesis as an alternative to Fama's proxy hypothesis in delineating the negative relationship between real stock returns and inflation. The Fama's proxy hypothesis claims that the negative real stock returns-inflation is indirectly explained by a negative real economic activity-inflation and positive real stock returns-real economic activity relationships. In Mundell-Tobin hypothesis, an increase in the expected rate of inflation causes portfolio substitution from money to financial assets, which will reduce the

\footnotetext{
${ }^{1}$ A hedge investment is one that contains two or more components. As the market conditions change, the change in the value of one of these parts at least partially offsets the change in the other component; if the change in the two positions offsets each other exactly, it is a perfect hedge. For example buying a stock and selling short the same stock would create a perfect hedge because as the stock rises in value, the increase in the long position would exactly be offset by a fall in value of the short position (French 1989: 419).

2 Among the studies on the developed countries includes Fama (1981, 1983; and 1990); Fama and Gibbons (1982); Geske and Roll (1983); Gultekin (1983a and 1983b); Kaul (1987 and 1990); Solnik (1973 and 1983); Boeckh and Coghlan (1982); and Malkiel (1982).
} 
Abd. Majid-Real Stock Returns, Inflationary Trends and Real Activity

real returns on such assets (for example, stocks). This reduction in real interest will stimulate real economic activity. Therefore, according to Mundell's hypothesis, one would expect a positive relationship between inflation and economic activity and a negative relationship between real stock returns and economic activity. ${ }^{3}$

Modigliani and Cohn (1982a) use the theory of rational valuation to explain the negative relationship between real stock returns and inflation. This theory contends that the low value of stocks during periods of high inflation is the result of the failure of investors to adjust corporate profits for the inflation premium components of interest expense (which they argue represents a return of capital rather than an expense) and from the capitalization of corporate profits at the nominal rate (rather than the theoretically correct real rate) of interest.

Wahlroos and Berglund (1986) also find a significant negative relationship when stock returns were regressed on the rate of inflation. Bulmash (1991) says that this negative stock returns-inflation relationship is indicated by the negative sloping curve, where the steepness of the slope depends on the magnitude of money supply changes.

The relationship between real stock returns and inflation is further explained by Day (1984) using a multi-period economy with production. He finds that the expected real returns-expected inflation relationship depends on the form of the economy's production function and investor preferences. When the production function exhibits stochastic constant returns to scale, the negative relation between expected real returns and expected inflation is documented. Bulmash (1991) on the other hand, adopts the quantity of money equation i.e. $M V=P Y$ to explain stock returns-inflation relationship. ${ }^{4} \mathrm{He}$ argues that if $M$ (nominal money growth) does not accommodate changes in $Y$ (output) as proxy of real economic activity, $P$ (price) will go up because changes in nominal money supply signal changes in inflation, then $Y$ will have to go down, thereby negatively affecting stock price.

Although researchers adopt different economic theories, different measures of inflation expectations and different econometric models to delineate the relationship between stock returns and inflation, they generally find that the stock markets in the developed economies were no longer a good hedge against inflation. This phenomenon is, of course, troublesome since it consistently appears to reject both economic theories and common sense. The consistent empirical findings for developed economies motivate a similar study for less developed economy by taking Malaysia as a case study. To the best of our knowledge, no study has been done in this area for the Malaysian stock market. As for the relationship between stock returns and inflation for developing countries, only two studies have been investigated, one on the Philippines case by Gultekin (1983a) and the other was on the Indian stock market by Chatrath et al. (1997). Unfortunately, their studies have many shortcomings. The former study ignores the role of expected and unexpected inflation in his model in the Philippines economy, while

\footnotetext{
3 Ram and Spencer (1983).

${ }^{4}$ There are many explanations on this theory, for example, see Froyen, R. T. (1996). We find that under the condition assumed the price level varies; (1) directly as the quantity of money (M), (2) directly as the velocity of its circulation (V), and (3) inversely as the volume of trade done by it (T). The first of these relations it worth emphasis. It constitutes the Quantity Theory of Money.
} 
the latter study employs too small sample size of data, from 1984 to 1996. Again, deficiencies in the previous studies provided additional motivation for this work, which intends to cover the shortfalls mentioned earlier.

There is, therefore, a growing need to address the question as to whether the Malaysian stock market provides an effective hedge against inflation? Does the behaviour of the Malaysian stock market coincide with the findings in developed countries? Is the Malaysian stock market in line with the Fisher hypothesis? Is the stock market of the country a good hedge against inflation? Does the Fama's proxy hypothesis explain the real stock returnsinflation relationship for the Malaysian market?

To answer the above questions, the paper aims at:

(1) Examining the relationship between real stock returns and inflationary trends in the Malaysian stock market, thereby testing the generalized Fisher hypothesis that real stock returns are independent of inflationary expectations

(2) Testing the Fama's Proxy hypothesis, which states that negative real stock returns-inflation relationship is indirectly explained by a negative inflation-real activity relationship and a positive real activity-stock returns relationship.

(3) Exploring whether the Fama's proxy effect is strong enough to explain negative stock returns-inflation relationship.

The above questions are necessary to be answered since the Malaysian economy has recently witnessed several measures, which are increasingly open to foreign investment (Kean 1989). As a result, institutional investors from developed countries such as America, Europe and Asian developed countries were attracted to this market. The spectacular performance of the Malaysian stock market may be related to inflation. ${ }^{5}$ Over the 1983 to 1996 period, the Kuala Lumpur Composite Index (KLC) rose sharply from approximately less than 300 to over 1200, while inflation, on the average, fluctuated from 0.1 percent to 4.4 percent. $^{6}$

The findings of this paper are expected to have important consequences to policymakers, international fund managers and other institutional investors who seek to diversify into the Malaysian stock market.

The remaining of the presentation of this paper is organized in the following sequence: In the next section, the hypotheses are stated. The methodology and data on which analysis is based are presented in section 3. Section 4 in turns discusses the results and implications of the paper. Lastly, section 6 concludes the paper.

\section{Statement of the Hypotheses}

Since the late 1960s and early 1970s, the stock markets in the developed countries have been found to be no longer an effective hedge against inflation (Malkiel 1982; and Boeckh and Coghlan 1982). Many studies have documented that actual, expected, unexpected inflation are all negatively related to stock returns. ${ }^{7}$ These empirical evidences appear contrary to

\footnotetext{
${ }^{5}$ This performance is specifically shown before the 1997 financial crisis attacked Malaysia.

${ }^{6}$ This particular economic data are retrieved from Datastream.

${ }^{7}$ Among the studies which found the stock returns are negatively related to inflationary trends, to name a few, are: Fama (1981); Geske and Roll (1983); Huizinga and Mishkin (1984); Wahlroos and Berglund (1986); and Chatrath et al. (1997).
} 
Abd. Majid-Real Stock Returns, Inflationary Trends and Real Activity

both economic theories and economic sense. Based on the previous empirical findings, the study expects changes in inflation rates to have a significant negative relation on the stock returns, thereby contradicting the Fisher hypothesis. The negative stock returns-inflation relation is expected to be strong enough to be explained by the Fama's proxy hypothesis.

\section{Methodology and Data}

\section{Testing Fisher Hypothesis}

In this study, we divide inflation into three types: actual, expected and unexpected inflation. Based on this, three econometric models are formulated to test the real stock return relationship to each type of inflation. The first model is between stock returns and actual inflation as in Graham's (1996) and Chatrath et al's. (1997):

$$
\mathrm{SR}_{\mathrm{t}}-\mathrm{INF}_{\mathrm{t}}=\beta_{0}+\beta_{1}\left(\mathrm{INF}_{\mathrm{t}}\right)+\varepsilon_{\mathrm{t}}
$$

Where $S R_{t}$ and $I N F_{t}$ are the nominal stock returns and the actual/contemporaneous rate of inflation over period $t$, respectively. The difference of $S R_{t}-I N F_{t}$ represents real (or inflation adjusted) returns and $e_{t}$ is the error random terms.

The second model is between stock returns and expected inflation as in Gultekin (1983a and 1983b); Solnik (1983); Leonard and Solt (1986); Wahlroos and Berglund (1986); Kaul (1987); and Chatrath et al. (1997). The model is presented as follows:

$\mathrm{SR}_{\mathrm{t}}-\mathrm{INF}_{\mathrm{t}}=\beta_{0}+\beta_{2} \mathrm{E}\left(\mathrm{INF}_{\mathrm{t}} \subseteq \phi_{\mathrm{t}-1}\right)+\varepsilon_{\mathrm{t}} \ldots$ (2)

Where $E\left(I N F_{t}\right)$ denotes the expected inflation rate at the time $t$ and $f_{t-1}$ is the informa- tion set available to investors at the end of period $t-1$.

The third model presents tests of the relationship between stock return and both expected and unexpected inflation as in Gultekin (1983a and 1983b); Geske and Roll (1983); Solnik (1983); Wahlroos and Berglund (1986); Leonard and Solt (1986); and Chatrath et al. (1997):

$$
\begin{aligned}
\mathrm{SR}_{\mathrm{t}}-\mathrm{INF}_{\mathrm{t}}= & \beta_{0}+\beta_{2} \mathrm{E}\left(\mathrm{INF}_{\mathrm{t}} \subseteq \phi_{\mathrm{t}-1}\right)+ \\
& \beta_{3}\left\{\mathrm{INF}_{\mathrm{t}}-\mathrm{E}\left(\mathrm{INF}_{\mathrm{t}} \subseteq \phi_{\mathrm{t}-1}\right)\right\}+ \\
& \varepsilon_{\mathrm{t}} \ldots \ldots \ldots \ldots \ldots \ldots \ldots \ldots \ldots . . . . \ldots \ldots \ldots \ldots \ldots \ldots \ldots \ldots
\end{aligned}
$$

However, model (3a) may be simplified as follows:

$$
\begin{aligned}
\mathrm{SR}_{\mathrm{t}}-\mathrm{INF}_{\mathrm{t}}= & \beta_{0}+\beta_{2} \mathrm{E}\left(\mathrm{INF}_{\mathrm{t}} \subseteq \phi_{\mathrm{t}-1}\right)+ \\
& \beta_{3} \mathrm{UE}\left(\mathrm{INF}_{\mathrm{t}}\right){ }_{+} \mathrm{e}_{\mathrm{t}} \ldots \ldots(3 \mathrm{~b})
\end{aligned}
$$

Where the unexpected inflation rate which is represented by $U E\left(I N F_{t}\right)$ is defined as the difference between actual inflation rate and expected rates of inflation, $\left\{I N F_{t}-\right.$ $\left.E\left(I N F_{t} \subseteq \phi_{t-1}\right)\right\}$.

For the first two equations, (1) and (2), if $\beta_{1}$ and $\beta_{2}$ coefficients equal to zero, the results will be consistent with Fisher hypothesis that states the real rate of returns on common stocks are independent of inflation rates. This implies that the stock market is a perfect hedge against inflation and expected inflation respectively. Meanwhile, the $\beta_{2}=\beta_{3}=0$ in the equation (3a) or (3b) means that the asset in question is a perfect hedge against both expected and unexpected inflation.

\section{Testing Fama's Proxy Hypothesis}

As mentioned earlier, the Fama's proxy hypothesis says that the negative relationship between stock returns and inflation centres around the linkages between inflation and real activity, and be- 
tween stock returns and real activity. The first proposition of Fama's proxy hypothesis - there is a negative relationship between inflation and real economic activity and the second proposition of Fama's proxy hypothesis - there is a positive association between real activity and stock returns, can individually be tested by the following models:

$$
\begin{aligned}
& \mathrm{INF}_{\mathrm{t}}=\alpha_{0}+\sum_{\mathrm{i}=-\mathrm{k}}^{\mathrm{k}} \beta_{\mathrm{i}} \mathrm{REA}_{\mathrm{t}+\mathrm{i}}+\varepsilon_{\mathrm{t}} \ldots . .(4 \mathrm{a}) \\
& \mathrm{E}\left(\mathrm{INF}_{\mathrm{t}}\right)=\alpha_{0}+\sum_{\mathrm{i}=-\mathrm{k}}^{\mathrm{k}} \alpha_{\mathrm{i}} \mathrm{REA}_{\mathrm{t}+\mathrm{i}}+\varepsilon_{\mathrm{t}} \ldots(4 \mathrm{~b}) \\
& \mathrm{UE}\left(\mathrm{INF}_{\mathrm{t}}\right)=\alpha_{0}+\sum_{\mathrm{i}=-\mathrm{k}}^{\mathrm{k}} \alpha_{\mathrm{i}} \mathrm{REA}_{\mathrm{t}+\mathrm{i}}+\varepsilon_{\mathrm{t}} \ldots(4 \mathrm{c}) \\
& \mathrm{SR} \mathrm{INF}_{\mathrm{t}}=\delta_{0}+\sum_{\mathrm{i}=-\mathrm{k}}^{\mathrm{k}} \delta_{\mathrm{i}} \mathrm{REA}_{\mathrm{t}+\mathrm{i}}+\mathrm{v}_{\mathrm{t}} \ldots .(5)
\end{aligned}
$$

Where $R E A_{t}$ is the real economic activity that is proxied by the Growth in Industrial Production (GIP), while $v_{t}$ represents the error random terms. Leading, contemporaneous, and lagging values of real economic activity are also incorporated in the model.

In line with Chatrath et al. (1997), in models (4a), (4b), (4c), and (5) we incorporate both leads and lags of real economic activity due to lack of prior evidence pertaining to the relationship of real economic activity with inflation and real returns in the Malaysian market. Equations (4a), (4b), and (4c) test the Fama's proposition (1). The negative relationship between inflation and real economic activity implies that some $\alpha_{i}$ 's are significantly negative. Equation (5) tests for Fama's proposition (2), where a positive relationship between real economic activity and real stock return implies that some $\delta_{i}$ 's are significantly positive.

Since the Fama's proxy effect explanation is based on an indirect relationship between real stock returns and inflation, a single equation treatment to equations (4a), (4b), (4c), and (5) may yield inconsistent estimates (Johnston 1984; Harvey 1990; and Chatrath et al. 1997). To avoid this inconsistency in the estimates of the relationship between stock returns and the actual, expected, and unexpected inflation, the study adopts Chatrath et al.'s (1997) two-step ordinary least square procedure. The models are as follows:

$$
\begin{array}{r}
\mathrm{INF}_{\mathrm{t}}=\mu_{0}+\sum_{\mathrm{i}=-\mathrm{k}}^{\mathrm{k}} \mu_{\mathrm{i}} \mathrm{REA}_{\mathrm{t}+\mathrm{i}}+\varepsilon_{\mathrm{t}} \ldots \ldots(6 \mathrm{a}) \\
\mathrm{SR}_{\mathrm{t}}-\mathrm{INF}_{\mathrm{t}}=\delta_{0}+\delta_{1} \varepsilon_{\mathrm{It}} \sum_{\mathrm{i}=-\mathrm{k}}^{\mathrm{k}} \delta_{\mathrm{i}} \mathrm{REA}_{\mathrm{t}+\mathrm{i}}+ \\
\mathrm{v}_{\mathrm{t}} \ldots \ldots \ldots \ldots \ldots \ldots \ldots \ldots . .(6 \mathrm{~b})
\end{array}
$$

$$
\mathrm{E}\left(\mathrm{INF}_{\mathrm{t}}\right)=\mu_{0}+\sum_{\mathrm{i}=-\mathrm{k}}^{\mathrm{k}} \mu_{\mathrm{i}} \mathrm{REA}_{\mathrm{t}+\mathrm{i}}+\varepsilon_{\mathrm{IIt}} \ldots \text { (7a) }
$$

$$
\begin{aligned}
& \mathrm{SR}_{\mathrm{t}}-\mathrm{INF}_{\mathrm{t}}= \delta_{0}+\delta_{1} \varepsilon_{\mathrm{IIt}} \sum_{\mathrm{i}=-\mathrm{k}}^{\mathrm{k}} \delta_{\mathrm{i}} \mathrm{REA}_{\mathrm{t}+\mathrm{i}}+ \\
& \pi_{\mathrm{t}} \ldots \ldots \ldots \ldots \ldots \ldots \ldots \ldots \ldots \ldots \ldots \ldots \ldots \ldots \ldots \ldots \ldots \ldots \\
& \ldots
\end{aligned}
$$

$$
\mathrm{UE}\left(\mathrm{INF}_{\mathrm{t}}\right)=\mu_{0}+\sum_{\mathrm{i}=-\mathrm{k}}^{\mathrm{k}} \mu_{\mathrm{i}} \mathrm{REA}_{\mathrm{t}+\mathrm{i}}+\varepsilon_{\mathrm{IIIt}}
$$

$$
\mathrm{SR}_{\mathrm{t}}-\mathrm{INF}_{\mathrm{t}}=\delta_{0}+\delta_{1} \varepsilon_{\mathrm{IIIt}} \sum_{\mathrm{i}=-\mathrm{k}}^{\mathrm{k}} \mu_{\mathrm{i}} \mathrm{REA}_{\mathrm{t}+\mathrm{i}}+
$$


Abd. Majid-Real Stock Returns, Inflationary Trends and Real Activity

For the last six equations (6a), (6b), (7a), (7b), (8a), and (8b), inflation and real stock returns are regressed on the lagging, contemporaneous, and leading values of real economic activity. However, the differences between equation (a) and (b), for example between equations (6a) and (6b) is where the estimated residual from equation (6a), $\varepsilon_{I t}$ is included as an independent variable in equation (6b) representing the inflation variable that is purged of the relationship between inflation and real economic activity. For equations (6b), (7b), and (8b), the $\delta_{l}$ coefficients are equal to zero, which will be consistent with Fama's proxy hypothesis that states real stock returns and inflation rates are independent once the impact of real economic activity on inflation has been controlled for. It means that if the persistence of the negative relationship between inflation and real stock returns still exists even after controlling for the inflation-real economic activity relationship, the results are inconsistent with the Fama's proxy hypothesis.

\section{The Data}

Fifteen years of quarterly changes in Consumer Price Index (CPI) is used as proxy for inflation and the Growth in Industrial Production $^{8}$ (GIP) is used as proxy for real economic activity. ${ }^{9}$ The data for stock returns are calculated from the Kuala Lumpur Stock Exchange (KLSE) Composite Index. ${ }^{10}$ The analysis are made on the quarterly non-seasonally adjusted data for the fifteen-year period from 1983: Q3 to 1998: Q2.

The stock returns are expressed as a percentage earned on a company's common stock investment for a given period and as a profitability ratio measuring how well equity capital is employed (Fitch et al. 1993). Nominal stock return is computed as follows:

$$
\mathrm{SR}_{\mathrm{t}}=\log \left\{\left(\mathrm{V}_{\mathrm{t}}\right) /\left(\mathrm{V}_{\mathrm{t}-1}\right)\right\}
$$

Where $V_{t}$ is the index value of stock at the end of quarter $t$ and $V_{t-1}$ is the index value of stock for previous quarter-end, $t-1$.

\section{Expected and Unexpected Inflation Forecasts $^{11}$}

In the developed countries, researchers generally use the Treasury Bill rate as a proxy for expected and unexpected inflation. This could be acceptable because the inflation rates in those countries are relatively constant almost all the time. However, in emerging markets like Malaysia, the inflation rates are relatively not constant. Similar to Fama and Gibbons (1982), Leonard and Solt (1986), Kaul (1990) and Chatrath et al. (1997), this study uses AutoRegressive Integrated Moving Average (ARIMA) model to estimate expected inflation and the forecast errors as the unexpected component of inflation. ${ }^{12}$ Another

\footnotetext{
${ }^{8}$ This index refers to the production of 64 industries selected from 23 major groups, covering 433 commodities [Bank Negara Malaysia. 1998. Monthly Statistical Bulletin (June)].

${ }^{9}$ The data for the study are compiled from Datastream and Bank Negara Malaysia Quarterly Bulletin.

${ }^{10}$ The Kuala Lumpur Composite Index (KLCI) is a value-weighted index that encompasses 100 stocks listed on Kuala Lumpur Stock Exchange (KLSE) until June 1998.

${ }^{11}$ Interested readers may consult the Fama and Gibbons (1984) and Leonard and Solt (1986) for details on the different forecasting methods of inflation.

${ }^{12}$ Otherwise known as Box-Jenkins (B-J), the ARIMA models owe their popularity to their tremendous success in forecasting time series. For example, Pankratz (1983) and Gujarati (1995) found that, in many cases, the forecasts obtained by this model are more reliable than those obtained from the conventional econometric modeling, particularly for short-term forecasts.
} 
reason for using ARIMA model in this study is that this particular model can detect large variability of inflation rates; hence it can achieve a greater predictability of the realized inflation rate (Solnik 1983).

\section{Empirical Results}

\section{The Test for Stationarity}

In order to obtain credible and robust results for any conventional regression analysis, the data to be analysed should be stationary (Pankratz 1983; Harvey 1990; Gujarati 1995). Table 1 shows the DickeyFuller (DF) test statistics that test the pres- ence of unit root test (non-stationarity) for all time series data, which are analysed in this study. In the test, the null-hypothesis is $\delta=0$, indicating that unit root exists. Failure to reject the null-hypothesis indicates no statistical evidence for stationary, while rejecting the null-hypothesis (accepting the alternative hypothesis) implies evidence for stationary.

Table 1 shows that the inflation rate (INF) is stationary in the log level either with constant and no trend regression model or with constant and trend regression model. However, in the log level, the KLCI is stationary for the regression model with constant and no trend, but non-stationary for the regression model with con-

Table 1. Dickey-Fuller Unit-Root Test

\begin{tabular}{|c|c|c|c|c|}
\hline \multirow[b]{2}{*}{ Variable } & \multicolumn{2}{|c|}{ Log Level } & \multicolumn{2}{|c|}{ First Differences } \\
\hline & $\begin{array}{c}\text { Constant and } \\
\text { No Trend }\end{array}$ & $\begin{array}{l}\text { Constant and } \\
\text { Trend }\end{array}$ & $\begin{array}{c}\text { Constant and } \\
\text { No Trend }\end{array}$ & $\begin{array}{c}\text { Constant and } \\
\text { Trend }\end{array}$ \\
\hline \multirow[t]{2}{*}{ INF } & $-2.7773 * * *$ & & & \\
\hline & & $-4.8482 * * *$ & - & - \\
\hline \multirow[t]{3}{*}{ KLCI } & & & $-3.8944 * * *$ & \\
\hline & $-2.8488 * * *$ & & & \\
\hline & & -2.7065 & & $-4.1780 * * *$ \\
\hline \multirow[t]{2}{*}{ REA } & -1.9573 & & $-6.2535 * * *$ & \\
\hline & & -1.1139 & & $-6.1601 * * *$ \\
\hline
\end{tabular}

Note:

INF is the rate of inflation computed from Consumer Price Index by $\log \left(\mathrm{CPI} / \mathrm{CPI}_{\mathrm{t}-1}\right)$. The Kuala Lumpur Composite Index (KLCI) is used as proxy for stock returns, which is calculated by log $\left(\mathrm{KLCI} / \mathrm{KLCI}_{\mathrm{t}-1}\right)$. Finally, REA or $\log \left(\mathrm{IPI}_{/} \mathrm{IPI}_{\mathrm{t}-1}\right)$ is the Industrial Production Index that is used as a proxy for the real economic activity.

*** represents a level of significance of $10 \%$.

The Dickey-Fuller test statistics for regression models with constant and no trend and with constant and trend are as follows:

$$
\begin{gathered}
\Delta \mathrm{y}_{\mathrm{t}}=\delta_{0}+\delta_{1} \mathrm{y}_{\mathrm{t}-1}+\sum_{\mathrm{j}=1}^{\mathrm{n}} \tau_{\mathrm{j}} \Delta \mathrm{y}_{\mathrm{t}-\mathrm{j}}+\mathrm{v}_{\mathrm{t}} \\
\Delta \mathrm{y}_{\mathrm{t}}=\delta_{0}+\delta_{1} \mathrm{y}_{\mathrm{t}-\mathrm{1}}+\delta_{2} \mathrm{~T} \sum_{\mathrm{j}=1}^{\mathrm{n}} \tau_{\mathrm{j}} \Delta \mathrm{y}_{\mathrm{t}-\mathrm{j}}+\mathrm{v}_{\mathrm{t}}
\end{gathered}
$$


Abd. Majid-Real Stock Returns, Inflationary Trends and Real Activity

stant and trend. Therefore, to achieve stationary for KLCI data in both models, the first differences are taken. On the other hand, the real economic activity (REA) is found non-stationary under the both models in the log level. Nevertheless, through the first difference for both models, stationarity is achieved.

\section{ARIMA Models for Expected and Unexpected Inflation Forecasts}

As for the ARIMA models, we begin with the identification stage, i.e. identify the exact order of Auto-Regressive (AR) $(p)$, Integrated (I) $(d)$, and order of Moving Average (MA) (q).

The unit-root test results (Table 1) imply that the rate of inflation is stationary at the log level, therefore the order of Integration is zero, I (0). As such, there is no need to differentiate it again in order to arrive at stationary. Since the inflation series is stationary, only the Auto-Regressive Moving Average (ARMA) $(p, q)$ is implemented. After identifying the I (0), the order of both Auto-Regressive (AR) and Moving Average (MA) shall be determined.

Through a diagnostic process, an ARMA $(0,7)^{13}$ is found to be the best model in specifying expected and unexpected inflation. The goodness of these chosen ARMA models is shown by Modified Box-Pierce chi-square statistics where all residuals from this model are insignificant. This indicates that the residuals from the chosen model are white noise. The other criteria for the fitness of the model are indicated by the computed values of
Table 2. ARMA Models for Expected Inflation

\begin{tabular}{|c|c|}
\hline Parameters & Expected Inflation \\
\hline MA (1) & $\begin{array}{c}-0.14231 \\
(-1.027)\end{array}$ \\
\hline MA (2) & $\begin{array}{c}-0.31463 * \\
(-2.640)\end{array}$ \\
\hline MA (3) & $\begin{array}{c}-0.21840 * * * \\
(-1.707)\end{array}$ \\
\hline MA (4) & $\begin{array}{c}-0.47687^{*} \\
(-4.718)\end{array}$ \\
\hline MA (5) & $\begin{array}{c}-0.23637 * * \\
(-2.150)\end{array}$ \\
\hline MA (6) & $\begin{array}{c}-0.53808 * \\
(-4.909)\end{array}$ \\
\hline MA (7) & $\begin{array}{l}0.18355^{* * * *} \\
(1.369)\end{array}$ \\
\hline Constant & $\begin{array}{c}0.00946 * \\
(3.423)\end{array}$ \\
\hline $\mathrm{R}^{2}$ & 0.2365 \\
\hline Skewness & 0.9704 \\
\hline Kurtosis & 5.4504 \\
\hline $\mathrm{J}-\mathrm{B}$ & 28.0391 \\
\hline $\mathrm{D}-\mathrm{W}$ & 1. 9372 \\
\hline
\end{tabular}

\section{Note:}

$J$ - $B$ indicates the Jarque-Bera test for normality, whereas $D-W$ refers to Durbin-Watson $d$ test. The numbers in the parentheses are $t$ statistics for testing the null-hypotheses that the coefficients are equal to zero.

$* ; * * * * *$ indicate significance at the $1 \%, 5 \%$, and $10 \%$ levels, respectively.

ARMA (0, 7) Model: $\begin{aligned} \mathrm{Y}_{\mathrm{t}}= & \phi+\beta_{0} \varepsilon_{\mathrm{t}}+\beta_{1} \varepsilon_{\mathrm{t}-1}+\beta_{2} \\ & \varepsilon_{\mathrm{t}-2}+\ldots+\mathrm{b}_{7} \mathrm{e}_{\mathrm{t}-7 .}\end{aligned}$

\footnotetext{
${ }^{13}$ The ARMA $(1,7)$ and ARMA $(3,7)$ are also found as fit models, which are indicated by the insignificance of their Box-Pierce chi-square statistics. This indicates that the residuals from the alternative models are also white noise. However, their R2, Skewness and Kurtosis values are $0.2513,1.00755$, and 5.36855 for the former, and $0.3061,1.22614$, and 6.82950 for the latter. Based on the parsimony criteria, therefore, the ARMA $(0,7)$ is the best-fit model. Even though, the models are not as parsimony as Ibrahim's $(1999 \mathrm{c})$ ARMA $(2,2)$ model, however, based on the criteria explained earlier, our models are good and fit enough.
} 
Skewness and Kurtosis. The values for these should be around 0 and 3 for normal distribution of the chosen model. ${ }^{14}$ If we look at these criteria, our results are not much departing from the normal or ideal values of 0 and 3 . For our model, ARMA $(0,7)$, the computed values of Skewness and Kurtosis are 0.9704 and 5.4504. Finally, based on normality test of JarqueBera (J-B) test, we find the $J-B$ values of 28.0391 and 7.9806, which asymptotically do not reject the normality assumption for our ARMA model. Having identified the appropriate $p, d$ and $q$ values, then estimation and forecasting steps are performed.

\section{The Real Stock Returns and Inflationary Trends}

Table 3 provides the test results for the relationship between real stock returns and inflation, thereby testing the general- ized Fisher hypothesis, which states that real stock returns are independent of inflationary expectations.

The coefficients for actual inflation $\left(\mathrm{INF}_{\mathrm{t}}\right)$, expected inflation $\mathrm{E}\left(\mathrm{INF}_{\mathrm{t}}\right)$, and unexpected inflation $\mathrm{UE}\left(\mathrm{INF}_{\mathrm{t}}\right)$ are all insignificant. The finding of the independent of real stock returns on inflationary trends in the Malaysian stock market support the Fisher hypothesis, but totally contradicts to recent findings, which found a negative relationship between real stock returns and inflation. This finding implies that the Malaysian stock market provides a good hedge against inflation. Whatever the inflation rates are, it does not affect the real stock returns for those who invest their money in this particular market. These results are also supported by the very low coefficient of determination $\left(\mathrm{R}^{2}\right)$, which measures the proportion or percentage of the total variation in real stock returns

Table 3. The Real Stock Returns and Inflationary Trends

\begin{tabular}{|c|c|c|c|c|c|c|c|}
\hline Model & Constant & $\mathrm{INF}_{\mathrm{t}}$ & $\mathbf{E}\left(\mathbf{I N F}_{\mathbf{t}}\right)$ & UE(INF $)$ & $\mathbf{R}^{2}$ & $\mathbf{F}$ & D-W \\
\hline 1 & $\begin{array}{l}-1.7925 \\
(-1.035)\end{array}$ & 11.743 & 11.743 & - & 0.0001 & 0.968 & 2.0660 \\
\hline 2 & $\begin{array}{c}-1.8740 \\
(-0.6966)\end{array}$ & - & $\begin{array}{c}34.970 \\
(0.1381)\end{array}$ & $\begin{array}{l}- \\
-\end{array}$ & 0.0004 & 0.651 & 2.0750 \\
\hline 3 & $\begin{array}{c}-1.9521 \\
(-0.7113)\end{array}$ & $\begin{array}{l}- \\
-\end{array}$ & $\begin{array}{c}43.123 \\
(0.1666)\end{array}$ & $\begin{array}{l}39.020 \\
(.2012)\end{array}$ & 0.0012 & 0.439 & 2.0938 \\
\hline
\end{tabular}

Note:

The numbers in the parentheses are the t-statistics for testing the null-hypothesis that the coefficients are equal to zero. Whereas D-W refers to Durbin-Watson $d$ test $*, * *, * * *$ represent a level of significance of $1 \%, 5 \%$, and $10 \%$, respectively.

The above regression results are obtained from the following models:

Model 1. $\quad \mathrm{SR}_{\mathrm{t}}-\mathrm{INF}_{\mathrm{t}}=\beta_{0}+\beta_{1}(\mathrm{INF})+\varepsilon$

Model 2. $\quad \mathrm{SR}_{\mathrm{t}}-\mathrm{INF}_{\mathrm{t}}=\beta_{0}+\beta_{2} \mathrm{E}\left(\mathrm{INF}_{\mathrm{t}} \neq \phi_{\mathrm{t}-1}\right)+\varepsilon_{\mathrm{t}}$

Model 3. $\quad \mathrm{SR}_{\mathrm{t}}-\mathrm{INF}_{\mathrm{t}}=\beta_{0}+\beta_{2} \mathrm{E}\left(\mathrm{INF}_{\mathrm{t}} \neq \phi_{\mathrm{t}-1}\right)+\beta_{3} \mathrm{UE}\left(\mathrm{INF}_{\mathrm{t}}\right)+\varepsilon_{\mathrm{t}}$

14 Gujarati, D. N. 1995. Basic Econometrics. 3rd Edition. New York: McGraw-Hill, Inc, pp. 773. 
Abd. Majid-Real Stock Returns, Inflationary Trends and Real Activity

explained by inflation. The independence of real stock returns on inflation is also supported by the insignificance of the $F$ statistics.

The above result supports the findings of Gultekin (1983a) for UK, Austria, France, Norway, Peru, and Sweden for the period from June 1947 to December 1979. Kaul (1987) also obtained similar results for USA and Canada for the period from 1926 to 1940 where he found independence of real stock returns on actual inflation.

The Durbin-Watson (D-W) $d$ statistics in Table 3 are all insignificant; hence we do not reject the null-hypothesis of having no auto-correlation among the disturbance terms. ${ }^{15}$

The $R^{2}$ of model (3) where real stock returns are regressed on unexpected inflation gives the highest $R^{2}$, which is 0.0012 , while the lowest $\left(\mathrm{R}^{2}=0.0001\right)$ is given by model (1) where real stock returns are regressed on actual inflation. This may indicate the importance of separating inflation into expected and unexpected inflation.

It should be noted that the present study as well as those preceding it exhibit rather low $R^{2}$ in most of the stock returninflation models; nominal or real. Bulmash (1991) noted that even adding other economic factors such as industrial production, money supply, real economic activity, and differences in interest ${ }^{16}$ still produced low $R^{2}$ of only 0.323 . His $R^{2}$ was high relative to other studies but still leaves 68 percent of stock returns variability unexplained.

\section{Tests for Fama's Proxy Hypothesis}

Testing the First Proposition of the Fama's Proxy Hypothesis: A Negative Relationship between Inflation and Real Economic Activity

Even though the finding shows an independency of stock returns on inflation which contradicts the Fama's proxy hypothesis, the study still continues to test both the Fama's propositions. This test is aimed at confirming the consistency of the Fama's proxy hypothesis in explaining the relationship between stock returns and inflation.

Table 4 reports the results for the first Proposition of the Fama's proxy hypothesis, which tests the presence of negative relationship between inflation ${ }^{17}$ and real economic activity. Earlier, we found the stock market proved to be a good hedge against inflation as suggested by the Fisher hypothesis (Table 3), which contradicts the Fama's proxy effect. Therefore, the results from the regression of inflation on real economic activity (Table 4) do contradict the Proposition (1) of the Fama's proxy effect. It contradicts because real stock returns are positively related to real economic activity instead of being negatively related.

Based on Table 4, the FPE-based specification models show that actual, expected and unexpected inflation are regressed on seven leading, contemporaneous, and lagging values of real economic. The optimal lead-lag lengths that are incorporated in the model are based on the Akaike's (1969) Final Prediction Error

${ }^{15}$ A simple way to test for serial correlation is by referring to the rule of thumb, where if $d$ is found to be close to 2 in application, one may assume that there is no first order auto-correlation, either positive or negative. See Gujarati, D. N. (1995): 423. Our results are around this number.

${ }^{16}$ As proxies for unexpected inflation as in Fama (1981).

${ }^{17}$ It is important to note that, the Fama's proxy effect deals only with the "actual inflation" and real economic activity, and does not deal with the other types of inflation; expected and unexpected inflation [see Fama (1981), such as Chatrath et al. (1997)]. 
Gadjah Mada International Journal of Business, September 2002, Vol. 4, No. 3

Table 4. Testing the First Proposition of the Fama's Proxy Hypothesis

\begin{tabular}{|c|c|c|c|c|c|}
\hline \multirow[t]{2}{*}{ Model } & \multicolumn{5}{|c|}{$\begin{array}{l}\text { Real Economic Activity: } \\
\text { Coefficients' Sum of Lead-Lag Specification }\end{array}$} \\
\hline & $\{-3.3\}$ & $\{-5.5\}$ & $\{-9.9\}$ & $\{-11.11\}$ & FPE \\
\hline 1 & $\begin{array}{l}0.000635^{*} \\
{[7.583]}\end{array}$ & $\begin{array}{l}0.001412 * \\
{[5.207]}\end{array}$ & $\begin{array}{c}0.004227^{*} \\
{[13.137]}\end{array}$ & $\begin{array}{c}0.003396^{*} \\
{[14.673]}\end{array}$ & $\begin{array}{c}0.004122 * \\
{[19.123]\{-7.7\}}\end{array}$ \\
\hline 2 & $\begin{array}{c}0.001161^{*} \\
{[26.783]}\end{array}$ & $\begin{array}{c}0.000332^{*} \\
{[25.910]}\end{array}$ & $\begin{array}{c}0.002229^{*} \\
{[18.910]}\end{array}$ & $\begin{array}{c}0.002294 * \\
{[12.884]}\end{array}$ & $\begin{array}{c}0.001755^{*} \\
{[28.279]\{-7.7\}}\end{array}$ \\
\hline 3 & $\begin{array}{c}0.000232 \\
{[1.391]}\end{array}$ & $\begin{array}{c}-0.001302 \\
{[1.140]}\end{array}$ & $\begin{array}{l}-0.000325 \\
{[2.240]}\end{array}$ & $\begin{array}{c}0.00328 * * \\
{[3.048]}\end{array}$ & $\begin{array}{c}0.001138 * \\
{[3.343]\{-7.7\}}\end{array}$ \\
\hline
\end{tabular}

Note:

The numbers in [.] are the $F$-statistics used for testing the null hypothesis that the coefficients' sum of lead-lag specification is equal to zero. The numbers in $\{$.$\} show the optimal lead-lag length based$ on the Akaike's (1969) Final Prediction Error criteria. These numbers of leading and lagging values of real economic activity, for example, $\{-3.3\}$ indicates that three leads and lags plus one contemporaneous value are incorporated in the model.

*, and $* *$ significance at the 1 percent and 5 percent levels, respectively

$$
\begin{aligned}
& \text { Model 1. } \mathrm{INF}_{\mathrm{t}}=\alpha_{0}+\sum_{\mathrm{i}=-\mathrm{k}}^{\mathrm{k}} \alpha_{\mathrm{I}} \mathrm{REA}_{\mathrm{t}+\mathrm{i}}+\varepsilon_{\mathrm{t}} \\
& \text { Model 2. E(INF) }=\alpha_{0}+\sum_{\mathrm{i}=-\mathrm{k}}^{\mathrm{k}} \alpha_{\mathrm{I}} \mathrm{REA}_{\mathrm{t}+\mathrm{i}}+\varepsilon_{\mathrm{t}} \\
& \text { Model 3. UE(INF) }=\alpha_{0}+\sum_{\mathrm{i}=-\mathrm{k}}^{\mathrm{k}} \alpha_{\mathrm{I}} \mathrm{REA}_{\mathrm{t}+\mathrm{i}}+\varepsilon_{\mathrm{t}}
\end{aligned}
$$

(FPE) criterion ${ }^{18}$ so as to avoid the inefficiency and biased parameter estimates from arbitrarily chosen lead-lag lengths. ${ }^{19}$ However, all possible lead-lag combinations with the minimum lead-lag length were also examined, ${ }^{20}$ but the discussion only focuses on FPE-based specification.
Table 4 shows that in a long-time period, there is a positive relationship between actual inflation and real economic. It is shown by the positive sum of lead-lag coefficients and significant $F$-statistics. It is found that the significant positive relationship between actual and expected in-

${ }^{18}$ The least value of Akaike's (1969) Final Prediction Errors (FPE) is considered as the optimal lead-lag length. It is computed by the formula: $\rho^{2}\{\mathrm{~N}+\mathrm{K}\} /\{\mathrm{N}-\mathrm{K})$. Where $\rho^{2}$ denotes variance, $N$ is the number of observation, and $\mathrm{K}$ is the number of explanatory variables excluding the constant term.

${ }^{19}$ In case of choosing too large lag length, the estimated parameters are inefficient due to the inclusion of irrelevant variables, while incorporating too small the lag length; the estimated coefficients will be biased due to the omission of important variables (Ibrahim. 1999c: 6). Another weakness of including arbitrary lead-lag lengths is that, it generally yields insignificant $F$-statistics (Ibrahim. 1999a: 11).

${ }^{20}$ In examining across all possible lead-lag combinations, the study only reports combination of lead-lag of $(-3.3),(-5.5),(-7.7),(-9.9)$, and (-11. 11). However, the maximum lead-lag length included in the models is only considered until (-12. 12). See, Ibrahim (1998c). 
Abd. Majid-Real Stock Returns, Inflationary Trends and Real Activity

flation with real economic activity (Model 1 and 2 ) is not only given by the FPE $\{-7$. $7\}$ model, but all the lead-lag combination models, which are all significant at the 1 percent level of significance. In general the FPE-based model compared to the other arbitrarily chosen lead-lag combination models show the highest $F$-Statistics. ${ }^{21}$ These significant positive relationships are also supported by regressing unexpected inflation on real economic activity. This finding is in contradiction with the first proposition of the Fama's proxy effect, but this fact may be consistent with the Philips' curve model.
Testing the Second Proposition of the Fama's Proxy Hypothesis: A Positive Relationship between Stock Returns and Real Economic Activity

Table 5 gives the results of the regression between real stock returns and real economic activity. The FPE based specification model $\{-1.1\}$ shows significant positive relationship at the 1 percent significant level. The lead-lag combinations of $\{-3.3\}$ and $\{-5.5\}$ are also significantly positive at the 5 percent level. This result, however, is not inconsistent with the Fama's proxy effect of proposition (2). However, the positive relationship between

Table 5. Testing the Second Proposition of the Fama's Proxy Hypothesis

\begin{tabular}{|c|c|c|c|c|c|c|}
\hline \multicolumn{7}{|c|}{$\begin{array}{l}\text { Real Economic Activity: } \\
\text { Coefficients' Sum of Lead-Lag Specification }\end{array}$} \\
\hline Model & $\{-3,3\}$ & $\{-5.5\}$ & $\{-7.7\}$ & $\{-9.9\}$ & $\{-11.11\}$ & FPE \\
\hline 1 & $\begin{array}{c}1.9788 * * \\
{[2.406]}\end{array}$ & $\begin{array}{l}\text { 2. } 1674 * * \\
{[2.280]}\end{array}$ & $\begin{array}{l}2.0844 \\
{[1.418]}\end{array}$ & $\begin{array}{c}-0.69395 \\
{[0.581]}\end{array}$ & $\begin{array}{r}-0.50455 \\
{[0.443]}\end{array}$ & $\begin{array}{c}1.1928^{*} \\
{[4.601]\{-1.1\}}\end{array}$ \\
\hline
\end{tabular}

Note:

The numbers in [.] are the $F$-statistics used for testing the null hypothesis that the coefficients' sum of lead-lag specification is equal to zero. The numbers in $\{$.$\} show the optimal lead-lag length based$ on the Akaike's (1969) Final Prediction Error criteria. These numbers of leading and lagging values of real economic activity, for example, $\{-3.3\}$ indicates that three leads and lags plus one contemporaneous value are incorporated in the model.

$*$, and $* *$ denote significance at the $1 \%$ and $5 \%$ levels, respectively.

$$
\text { Model 1. } \mathrm{SR}_{\mathrm{t}}-\mathrm{INF}_{\mathrm{t}}=\alpha_{0}+\sum_{\mathrm{i}=-\mathrm{k}}^{\mathrm{k}} \alpha_{\mathrm{I}} \mathrm{REA}_{\mathrm{t}+\mathrm{i}}+\varepsilon_{\mathrm{t}}
$$

${ }^{21}$ Ibrahim (1999a) found similar results. 
Gadjah Mada International Journal of Business, September 2002, Vol. 4, No. 3

Table 6. Real Stock Returns, Inflationary Trends, and Real Economic Activity

\begin{tabular}{|c|c|c|c|}
\hline $\begin{array}{c}\text { Lead-Lag } \\
\text { Specification }\end{array}$ & $\begin{array}{c}\text { Real Economic } \\
\text { Activity: Estimated } \\
\text { and Sum } \\
\text { of Coefficients }\end{array}$ & $\begin{array}{c}\text { Lead-Lag } \\
\text { Specification }\end{array}$ & $\begin{array}{c}\text { Real Economic } \\
\text { Activity: Estimated } \\
\text { and Sum } \\
\text { of Coefficients } \\
\end{array}$ \\
\hline$\frac{\text { Model 1 }}{\{-3.3\}}$ & $1.9764 * *$ & \multirow{4}{*}{$\begin{array}{l}\varepsilon_{\mathrm{IIt}} \\
\mathrm{FPE}\end{array}$} & $\begin{array}{l}0.2475 \\
{[0.258]}\end{array}$ \\
\hline$\{-5.5\}$ & $\begin{array}{c}{[2.0930]} \\
2.1485 * * \\
{[2.054]}\end{array}$ & & $\begin{array}{l}-23.414 \\
(-0.0467) \\
1.3104 * *\end{array}$ \\
\hline$\{-7.7\}$ & $\begin{array}{l}2.0470 \\
{[1.298]}\end{array}$ & & $\begin{array}{c}\qquad 3.015]\{\mathbf{- 1 . 1}\} \\
\mathbf{R}^{2}=0.2315 \\
\text { Adjusted- } \mathbf{R}^{2}=0.1632\end{array}$ \\
\hline$\{-9.9\}$ & $\begin{array}{l}-0.7356 \\
{[0.556]}\end{array}$ & & $\begin{array}{c}\text { Adjusted- } \mathbf{R}^{2}=0.1632 \\
\text { D-W }=1.6459 \\
\text { J-B }=373.911\end{array}$ \\
\hline$\{-11.11\}$ & $\begin{array}{l}-0.5045 \\
{[0.425]}\end{array}$ & $\frac{\text { Model } 3}{\{-3.3\}}$ & (5) \\
\hline \multirow[t]{3}{*}{$\begin{array}{l}\varepsilon_{\mathrm{It}} \\
\mathrm{FPE}\end{array}$} & $\begin{array}{c}83.314 \\
(0.2576) \\
1.1875^{*} \\
{[3.629]\{\mathbf{- 1 . 1}\}}\end{array}$ & $\{-5.5\}$ & $\begin{array}{l}\{0.639] \\
-0.2415 \\
{[0.744]}\end{array}$ \\
\hline & $\begin{array}{c}\quad \mathbf{R}^{2}=0.2362 \\
\text { Adjusted- } \mathbf{R}^{\mathbf{2}}=0.1774\end{array}$ & $\{-7.7\}$ & $\begin{array}{l}0.8274 \\
{[0.487]}\end{array}$ \\
\hline & $\begin{array}{l}\mathbf{D}-\mathbf{W}=2.2121 \\
\mathbf{J}-\mathbf{B}=572.107\end{array}$ & $\{-9.9\}$ & $\begin{array}{l}0.1180 \\
{[0.408]}\end{array}$ \\
\hline$\frac{\text { Model 2 }}{\{-3.3\}}$ & 0.2271 & $\{-11.11\}$ & $\begin{array}{l}-0.6384 \\
{[0.332]}\end{array}$ \\
\hline & $\{0.586]$ & $c_{\text {IIIt }}$ & 94.095 \\
\hline$\{-5.5\}$ & $\begin{array}{l}-0.2358 \\
{[0.697]}\end{array}$ & FPE & $\begin{array}{l}(0.3086) \\
1.3110^{*}\end{array}$ \\
\hline$\{-7.7\}$ & $\begin{array}{l}0.8404 \\
{[1.298]}\end{array}$ & & $\begin{array}{c}{[3.040]\{\mathbf{- 1 . 1}\}} \\
\mathbf{R}^{2}=0.2331\end{array}$ \\
\hline$\{-9.9\}$ & $\begin{array}{r}-0.0267 \\
{[0.380]}\end{array}$ & & $\begin{array}{c}\text { Adjusted- } \mathbf{R}^{2}=0.1649 \\
\mathbf{D}-\mathbf{W}=1.6486 \\
\mathbf{J}-\mathbf{B}=371.725\end{array}$ \\
\hline
\end{tabular}

Note:

The numbers in (.) and [.] are the t-statistics and F-statistics, respectively used for testing the null hypothesis that estimated and coefficients' sum are equal to zero. The $\{$.$\} is the optimal lag length$ based on Akaike's (1969) Final Prediction Error (FPE) criteria.

$J-B$ and $D$ - $W$ represent the Jarque-Bera test for normality and Durbin-watson $d$ test, respectively. $*$ and $* *$ denote the levels of significance of 1 percent and 5 percent, respectively. 
Abd. Majid-Real Stock Returns, Inflationary Trends and Real Activity

$$
\begin{aligned}
& \underline{\text { Model 1. }} \mathrm{SR}_{\mathrm{t}}-\mathrm{INF}_{\mathrm{t}}=\delta_{0}+\delta_{1} \varepsilon_{\mathrm{It}}+\sum_{\mathrm{i}=-\mathrm{k}}^{\mathrm{k}} \delta_{\mathrm{i}} \mathrm{REA}_{\mathrm{t}+1}+v_{\mathrm{t}} \\
& \mathrm{INF}_{\mathrm{t}} \quad=\mu_{0}+\sum_{\mathrm{i}=-\mathrm{k}}^{\mathrm{k}} \mu_{\mathrm{i}} \mathrm{REA}_{\mathrm{t}+1}+\varepsilon_{\mathrm{It}} \\
& \text { Model 2. } \mathrm{SR}_{\mathrm{t}}-\mathrm{INF}_{\mathrm{t}}=\delta_{0}+\delta_{1} \mathrm{e}_{\mathrm{Iit}}+\sum_{\mathrm{i}=-\mathrm{k}}^{\mathrm{k}} \delta_{\mathrm{i}} \mathrm{REA}_{\mathrm{t}+1}+\pi_{\mathrm{t}} \\
& \mathrm{E}\left(\mathrm{INF}_{\mathrm{t}}\right)=\mu_{0}+\sum_{\mathrm{i}=-\mathrm{k}}^{\mathrm{k}} \mu_{\mathrm{i}} \mathrm{REA}_{\mathrm{t}+1}+\varepsilon_{\mathrm{Iit}} \\
& \text { Model 3. } \mathrm{SR}_{\mathrm{t}}-\mathrm{INF}_{\mathrm{t}}=\delta_{0}+\delta_{1} \mathrm{e}_{\text {IIIt }}+\sum_{\mathrm{i}=-\mathrm{k}}^{\mathrm{k}} \delta_{\mathrm{i}} \mathrm{REA}_{\mathrm{t}+1}+\varphi_{\mathrm{t}} \\
& \mathrm{UE}\left(\mathrm{INF}_{\mathrm{t}}\right)=\mu_{0}+\sum_{\mathrm{i}=-\mathrm{k}}^{\mathrm{k}} \mu_{\mathrm{i}} \mathrm{REA}_{\mathrm{t}+1}+\varepsilon_{\mathrm{IIIt}}
\end{aligned}
$$

inflation and real economic activity and the positive relationship between real stock returns and real economic activity show some consistencies with the explanation of conventional macroeconomic theories of the Philip's curve. ${ }^{22}$

\section{Real Stock Returns, Inflationary Trends, and Real Economic Activity}

The finding of the paper so far is consistent enough since it shows the independence of inflation on real stock returns, therefore none of them supports the Fama's proxy hypothesis when both propositions of the Fama's proxy hypothesis are regressed in isolation. Since the framework of the Fama's proxy effect is based on an indirect relationship between stock returns and inflation, this study tries to examine the extent to which the Fama's proxy effect is consistent and valid to explain the negative stock returns-inflation relationship. Table 6 reports the results from three regressions of the real stock returns on the purged actual, expected, and unexpected inflation.

Table 6 presents the regression results of real stocks on the purged actual, expected and unexpected inflation as well as lagging, contemporaneous and leading values of real economic activity. One lagging, contemporaneous, and leading values are identified as the FPE-based specification for each model.

Table 6 finds that the independence of real stock returns on inflationary trends

\footnotetext{
${ }^{22}$ The independence of real stock returns and inflationary trends, it appears to be in contradiction with the Philips curve. However, if we scrutinize well, it should not appear so. The positive both inflation-real economic activity and real stock returns-real economic activity are not always to be shown by the positive relationship between real stock returns and inflation. Because there is a possibility to find the independence of real stock returns on inflation when real economic activity-inflation and real stock returns-real economic activity are found positively significance to each other.
} 
for Malaysia (Table 3) still exists even the effect of real economic activity on inflation has been controlled for. ${ }^{23}$ The study does not reject the null hypothesis that the finding is still in line with the Fisher hypothesis. It is indicated by the insignificance of $\varepsilon_{I t}, \varepsilon_{I I t}$, and $\varepsilon_{I I t t}$. Since the Fama's proxy hypothesis explains the negative relationship between stock returns and inflation, therefore, this theory cannot be used to explain the independence between variables as observed for Malaysia. In general, the results from Table 3 and Table 6 are not much different. These results show that the Fama's proxy effect framework cannot totally explain the independence of real stock returns on inflationary trends.

\section{Conclusions}

The well-documented negative relationships between real stock returns and inflationary trends in the developed countries are not supported by the findings for the Malaysian economy. The real stock returns are found to be independent of inflationary trends as suggested by the Fisher hypothesis, which implies that, the real stock returns is a good hedge against inflation.

In an effort to explain the relationship between real stock returns and inflation, the study examined both propositions of the Fama's proxy effect framework, which centres around a negative relationship between inflationary trends and real economic activity and a positive relationship between real stock returns and real economic activity. A positive real economic activity-inflation and a positive real economic activity-real stock returns relationship were recorded, which totally contradict the Fama's proxy effect, but however are in line with the conventional macroeconomic Philips' curve theory. The consistency of the Fama's proxy hypothesis was then tested by introducing a twostep estimation that controlled for the inflation-real economic activity relationship. The study still found independence between real stock returns and inflation, which consistently against Fama's proxy hypothesis.

\footnotetext{
${ }^{23}$ Once the effect of real economic activity on inflation has been controlled for, the inflationary trends that were significant should not be. For this purpose, Wahlroos and Berglund (1986) simply tested their model by including the real economic activity as independent variable into the real stock returns-expected and unexpected relationship's models. Their results are not much difference with this study.
} 
Abd. Majid-Real Stock Returns, Inflationary Trends and Real Activity

\section{References}

Akaike, H. 1969. Fitting autoregressive models for prediction. Annals of the Institute of Statistical Mathematics 21: 234-247.

Bank Negara Malaysia. Quarterly Statistical Bulletin (on various issues).

Boeckh, A. J., and R. T. Coghlan. 1982. An overview of the impact of inflation on the stock market. In Boeckh, A. J., and R. T. Coghlan (Ed.). The Stock Market and Inflation. Homewood, Illinois: Dow Jones-Irwin.

Brigham, E. F. 1986. Fundamentals of Financial Management (4 ${ }^{\text {th }}$ Ed.). New York: The Dryden Press.

Brigham, E. F., and L. C. Gapenski. 1987. Intermediate Financial Management. $2^{\text {nd }}$ Edition. New York: The Dryden Press.

Buffett, W. E. 1982. How inflation swindles the equity investors. In Boeckh, A. J., and R. T. Coghlan (Ed). The Stock Market and Inflation. Homewood, Illinois: Dow JonesIrwin.

Bulmash, S. B. 1991. Stock prices, inflation, and money supply: A re-examination. In Chen, S. N., and L. C. Few (Ed.). Advances in Investments Analysis and Portfolio Management. London, England: JAI Press. Inc.

Campbell, T. S. 1982. Financial Institutions, Markets, and Economic Activity. New York: McGraw-Hill, Inc.

Chatrath, A. R. S., and F. Song. 1997. Stock prices, inflation and output: Evidence from India. Applied Financial Economics 7: 439-445.

Chen, N. F., R. Roll, and S. A. Ross. 1986. Economic forces and the stock market. Journal of Business 59 (3) (July ): 383-403.

Copeland, T. E., and J. F. Weston. 1998. Financial Theory and Corporate Policy. ( ${ }^{\text {rd }}$ Ed.). United States of America: Addison-Wesley Publishing Company.

Day, Th. E. 1984. Real stock returns and inflation. The Journal of Finance 39 (2) (June): 493-502.

Derrick, G. H. 1985. Dictionary of Banking and Finance: A Contemporary on Banking, Financial Services and Corporate Personal Finance. London: Pitman Publishing, Inc.

Fama, E. F. 1981. Stock returns, real activity, inflation, and money. American Economic Review 71 (September): 545-565.

1983. Stock returns, real activity, inflation, and money: reply. The American Economic Review 73 (June): 471-472.

1990. Stock returns, expected returns, and real activity. The Journal of Finance 55 (4) (September): 1089-1108. 
Fama, E. F., and M. R. Gibbons. 1982. Inflation, real returns and capital investment. Journal of Monetary Economics 9: 297-323. ics 13: 327-348.

.1984. A comparison of inflation forecast. Journal of Monetary Econom-

Fisher, I. 1930. The Theory of Interest. New York: Macmillan, Inc.

Fitch, P. T, I. Kellner, G. D. Simonson, and B. Weberman. 1993. Dictionary of Banking Terms. New York: Barron's Educational Series, Inc.

French, D. W. 1989. Security and Portfolio Analysis: Concepts and Management. Columbus, Ohio: Merill Publishing Company.

Froyen, R. T. 1996. Macroeconomics: Theories and Policy $\left(5^{\text {th }}\right.$ Ed.). United State of America: Prentice Hall, Inc.

Geske, R., and R. Roll. 1983. The fiscal and monetary linkage between stock returns and inflation. The Journal of Finance 38 (1) (March): 1-33.

Graham, F.C. 1996. Inflation, real stock returns, and m onetary policy. Applied Financial Economics 6: 29-35.

Gujarati, D. N. 1995. Basic Econometrics ( ${ }^{\text {rd }}$ Ed.). New York: McGraw-Hill, Inc.

Gultekin, B. N. 1983a. Stock market returns and Inflation: Evidence from other countries. The Journal of Finance 38 (1) (March): 49-65.

1983b. Stock market returns and inflation forecasts. The Journal of Finance 38 (3) (June ): 663-673.

Hamburger, M. J., and B.Zwick. 1981. Deficit, money and inflation. Journal of Monetary Economics 7: 141-150

Harvey, A. C. 1990. The Econometric Analysis of Time Series ( ${ }^{\text {nd }}$ Ed.). New York: Philip Alan.

Hasbrouck, J. 1984. Stock returns, inflation, and economic activity: The survey evidence. The Journal of Finance 39 (4) (December): 1293-1310.

Ibbotson, R. G., and Sinquefield, R. A. 1989. Stocks, Bonds, Bills, and Inflation: Historical Returns (1926-1987). Charlottesville, Virginia: The Research Foundation of the Institute of Chartered Financial Analyst.

Ibrahim, M. H. 1999a. Macroeconomic variables and stock prices in Malaysia: An empirical analysis. Asian Economic Journal 13 (2): 219-231.

1999b. Money and the informational efficiency of Malaysian Stock Market: A re-assessment. Prajnan: Journal of Social and Management Sciences 28 (1): 17-32.

1999c. Money, exchange rate and inflationary dynamics in Malaysia: A post forecast evaluation. Asian-Pacific Development Journal 6 (2): 69-85. 
Abd. Majid-Real Stock Returns, Inflationary Trends and Real Activity

James, C. K. S., and M. Partch. 1985. A VARMA analysis of the causal relations among stock returns, real output, and nominal interest rate. The Journal of Finance 11 (5) (December ): 1375-1384.

Johnston, J. 1984. Econometric Methods ( $3^{\text {rd }}$ Ed.). New York: McGraw-Hill Book Company.

Kaul, G. 1987. Stock returns and inflation: The role of monetary sector. Journal of Financial Economics 18: 253-276.

1990. Monetary regimes and the relation between stock returns and inflationary expectations. Journal of Financial and Qualitative Analysis 25: 307321.

Kean, S. N. 1989. Stock Market Investment in Malaysia and Singapore (New Edition). Kuala Lumpur: Berita Publishing Sdn. Bhd.

Kopcke, R. W. 1982. Stock are not an inflation hedge. In Boeckh, A. J. and Coghlan, R. T. (Ed). The Stock Market and Inflation. Homewood, Illinois: Dow Jones-Irwin.

Lee, U. 1998. A test of the proxy-effect hypothesis: Evidence from the Pacific Basin countries. QJBE 37 (3): 40-52.

Leonard, D. C., and M. E. Solt. 1986. Recent evidence on the accuracy of rationality of popular inflation forecast. Journal of Financial Research 9 (Winter): 281-290.

Leuthold, S. C. 1982. The myth of common stocks and inflation. In Boeckh, A. J. and Coghlan, R. T. (Ed.). The Stock Market and Inflation. Homewood, Illinois: Dow Jones-Irwin.

Malkiel, B. G. 1982. U.S. equities as an inflation hedge. In Boeckh, A. J. and Coghlan, R. T. (Ed). The Stock Market and Inflation. Homewood, Illinois: Dow Jones-Irwin.

Marshall, D. A. 1992. Inflation and asset returns in a monetary economy. The Journal of Finance 47 (4) (September): 1315-1342.

Mishkin, F. S. 1982. Monetary policy and short term interest rates: An efficient market rational expectations approach. The Journal of Finance. 37 (March): 63-71. Limited.

Mishkin, F. S., and Huizinga. 1986. Monetary policy regime shifts and the unusual behaviour of real interest rates. in M. Frederic. (Ed.). Money, Interest, and Inflation. England: Edward Elgar Publishing Limited.

Modigliani, F., and A. R. Cohn. 1982a. Inflation and stock market. in Boeckh, A. J. and Coghlan, R. T. (Ed.). The Stock Market and Inflation. Homewood, Illinois: Dow Jones-Irwin, Inc.

1982b. Inflation, rational valuation, and the market. in Szego, G. P., and Sarnat, M. (Ed.). Saving, Investment, and Capital Markets in an Inflationary Economy. United States of America: Ballinger Publishing Company. 
Pankratz, A. 1983. Forecasting with Univariate Box-Jenkins Models: Concepts and Cases. United States of America: John Wiley and Sons, Inc.

Philips, A. W. 1958. The relationship between unemployment and the rate of change of money wages rates in the United Kingdom, 1961-1957. Economica 25 (November): 283-299.

Ram, R., and D. E. Spencer. 1983. Stock returns, real activity, inflation, and money: Comment. American Economic Review 73 (June): 463-470.

Reilly, F. K., and K. C. Brown. 1997. Investment Analysis and Portfolio Management $\left(5^{\text {th }}\right.$ Ed.) United States of America: The Dryden Press. Harcourt Brace College Publishers.

Rosylin. M. Y. 1993. A model of inflation in Malaysia: 1970-1990. M.Ec Research Paper (March ). International Islamic University Malaysia.

Sangkyun, P. 1997. Rationality of negative stock-price responses to strong economic activity. Financial Analysts Journal 3 (September/October): 52-56.

Schwert, W. G. 1990. Stock returns and real activity: A century of evidence. The Journal of Finance 55 (4) (September ): 1237-1257.

Serletis, A. 1993. Money and stock prices in the United States. Applied Financial Economics 3: 51-54.

Shazam. 1997. The Econometrics Computer Program Version 8.0: Users's Reference Manual. Canada: McGraw-Hill Companies.

Siegel, L. B., and D. Montgomery. 1995. Stocks, bonds, and bills after taxes and inflation. The Journal of Portfolio Management 5 (Winter ): 17-25.

Solnik, B. 1983. The relationship between stock prices and inflationary expectations: The international evidence. The Journal of Finance 38 (1) (March ): 35-48.

. 1973. Some International Evidence on Output-Inflation Tradeoffs. American Economic Review 63 (June ): 326-334.

Teweles, R. J., and E. S. Bradley. 1987. The Stock Market (5 ${ }^{\text {th }}$ Ed.) New York: John-Wiley and Sons, Inc.

Thorton, J. 1993. Money, output and stock prices in the UK: Evidence on some (non) relationship. Applied Financial Economics 3: 335-338.

Trevithick, J. A. 1975. The Economics of Inflation. London: Martin-Robertson and Co. Limited.

Wahlroos, B., and T. Berglund. 1986. Stock returns, inflationary expectations and real activity: New evidence. Journal of Banking and Finance 10: 377-389. 